\title{
Comparing Aboveground Carbon Sequestration of Three Economically Important Bamboo Species Grown in Bukidnon, Philippines
}

\author{
Jose Hermis P. Patricio and Scarlet Wine L. Dumago \\ Department of Environmental Science, College of Forestry and Environmental \\ Science, Central Mindanao University, University Town, \\ Musuan, Bukidnon 8710, Philippines \\ Corresponding author: Jose Hermis P.Patricio, email: sporting_ph@yahoo.com
}

\begin{abstract}
Bamboo is widely distributed in the Philippines. As a non-timber forest product with a wide-ranging economic importance, bamboo has attracted the attention of ecologists because of its versatility in terms of ecological services including carbon sequestration and its potential to mitigate climate change. This paper assessed the carbon sequestration potential of three economically important bamboo species grown in plantations in Bukidnon, Philippines. Aboveground biomass (leaves, twigs and branches, and culms) and carbon densities of plantations of Dendrocalamus asper, Bambusa blumeana and Bambusa vulgaris were determined. $D$. asper statistically $(\alpha=0.01)$ had the highest aboveground biomass density with $177.6 \mathrm{t} \mathrm{ha}^{-1}$ while $B$. vulgaris had the lowest density with $72.2 \mathrm{t} \mathrm{ha}^{-1}$. Aboveground biomass of the three species yielded an average organic carbon content of $47.38 \%$ with $D$. asper having the highest at $48.71 \%$. Consequently, $D$. asper statistically $(\alpha=0.01)$ had the highest aboveground carbon stored with an average of $86.7 \mathrm{tC} \mathrm{ha}^{-1}$, followed by B. blumeana with $46.1 \mathrm{tC} \mathrm{ha}^{-1}$ and B. vulgaris with $33.4 \mathrm{tC} \mathrm{ha}^{-1}$. Considering the potential of these bamboo species to store atmospheric carbon, there is a need to propose policies that strongly advocate the establishment of bamboo plantation-related projects in the country as an alternative course of action that can mitigate the impacts of global warming and climate change. Planting and managing bamboo plantations are recommended utilizing species like $D$. asper which has the potential to sequester relatively higher amount of carbon.
\end{abstract}

Keywords: biomass, climate, ecological, plantations, warming 


\section{Introduction}

Climate change caused by global warming is considered to be the most pressing environmental problem mankind is facing today. The Intergovernmental Panel on Climate Change [IPCC] (2013) claimed in its latest (5th assessment) report that "each of the last three decades has been successively warmer at the Earth's surface than any preceding decade since 1850." From 1850-2012, combined data on land and ocean temperature showed that the earth has warmed by an average of $0.85{ }^{\circ} \mathrm{C}$. Such extent of warming is a strong indication of the unprecedented rise in levels of carbon dioxide, methane, and nitrous oxide in the last 800,000 years. In 2011, the concentration of $\mathrm{CO}_{2}$ was 391 ppm, which exceeded the pre-industrial levels by about forty percent.

One way to manage atmospheric carbon is through sequestration. Carbon sequestration is the elimination of carbon dioxide from the atmosphere and storing it to long-term carbon sink such as plants. One of these plants is bamboo which holds great promise because of its fast growing characteristics. Bamboo can be one of the potential species for plantation in degraded or wastelands to act as a carbon sink in the sense that it contains biomass that stores a large quantity of carbon (Maoyi, 2007).

Realizing not only the economic importance of bamboo but also its role in climate change mitigation through carbon sequestration, the government through the Department of Environment and Natural Resources (DENR) embarked on bamboo research and development project in various sites of the country including Bukidnon. The province has about 1228 ha of bamboo stands (Virtucio \& Roxas, 2003) which are planted with commercially important species including Dendrocalamus asper (Schult. f.) Backer ex Heyne (giant bamboo), Bambusa blumeana Schult. f. ("kawayan tinik"), and Bambusa vulgaris Schrad. ex J.C. Wendl. ("kawayan kiling"). Decipulo et al. (2009) cited that approximately $87 \%$ of the area has been planted with $D$. asper, while the rest is grown with B. blumeana, B. vulgaris, Gigantochloa levis and other bamboo species. $D$. asper plantations were about 27 years old as they were established in 1986 while B. blumeana and B. vulgaris plantations were about 24 years old since these were established in 1989. The Center for Ecological Development and Recreation (CEDAR) of the DENR and the local 
government units of Impasugong and Malaybalay City co-manage these bamboo plantations.

The growing interest in forest plantation species like bamboo in increasing carbon sinks as a mitigation strategy can be attributed to its inexpensiveness, high carbon uptake potential, and associated socioeconomic and environmental benefits. Given this background, it is important therefore to generate a pool of reliable information on carbon sequestration ability of $D$. asper, B. blumeana, and B. vulgaris that will serve as the basis for more effective interventions in managing and developing bamboo plantations. Hence, this paper is a synthesis of the potential of the above-mentioned bamboo species to sequester atmospheric carbon.

\section{Materials and Methods}

\section{Locale of the study}

The study site for $D$. asper plantation was situated in Impasugong while B. blumeana, and B. vulgaris plantations were in Malaybalay City, both in Bukidnon Province, Philippines (Figure 1). Impasugong is strategically located in the northeastern part of Bukidnon Province with geographical coordinates of $8^{0} 7^{\prime}$ to $8^{0} 35^{\prime}$, north latitude and $124^{0} 18^{\prime}$ to $125^{\circ} 18^{\prime}$ east longitude. Almost $60 \%$ of the municipality has an elevation range of 501 to 1000 meters above sea level (masl) with an average elevation of $647 \mathrm{~m}$ (Municipal Planning and Development Office [MPDO], 2000). The dominant slope is $18 \%$ and above which covers almost $72 \%$ of the municipality's area making it mountainous and with deep canyons and gorges. On the other hand, Malaybalay City, which is the capital of the province, is situated in the central part of the province with coordinates of $8^{0} 9^{\prime}$ north latitude and $125^{\circ} 5^{\prime}$ east longitude. On the average, the city is elevated (622 masl), and about $60 \%$ of its land area is above $30 \%$ slope. Consequently, it is characterized with steep hills, mountains and cliff-like streamside with the rest of the areas rolling and hilly.

In terms of climate, Impasugong is characterized to be cool and moist throughout the year due to its high elevation (MPDO, 2003). The area is under Type 3 climate which is characterized by the absence of pronounced maximum rainy period and a short dry season lasting from 
one to three months, usually starting from February up to April. Average temperature ranges from 16 to $31^{\circ} \mathrm{C}$ throughout the year. For the past five years, the heaviest rainfall occurred in June with $431.7 \mathrm{~mm}$ and the lowest in March with only $89.2 \mathrm{~mm}$. It is a typhoon-free area, ideal for the production of high-value crops.

Meanwhile, Malaybalay City falls under Type 4 climate, which is characterized by the absence of a pronounced maximum rainy period and dry season. The months of May to October are usually characterized with heavy rains while November to April is relatively drier period. The average annual temperature and precipitation in Malaybalay is $23.4{ }^{\circ} \mathrm{C}$ and $2664 \mathrm{~mm}$, respectively. March is the driest with $115 \mathrm{~mm}$ rainfall while September is the wettest with an average of $328 \mathrm{~mm}$ rainfall. On the other hand, May is the warmest with an average temperature of $24.4{ }^{\circ} \mathrm{C}$ while January is the coolest with an average of $22.5^{\circ} \mathrm{C}$. Compared with the rest of the country, the climate in Malaybalay is relatively cooler the whole year round, and the area is not on the typhoon belt.

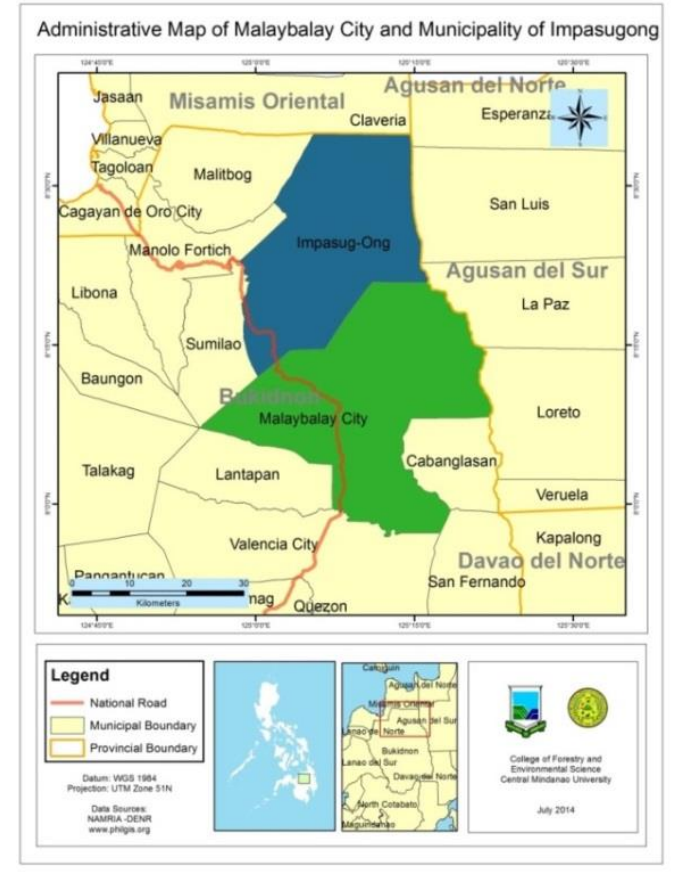

Figure 1. Location map of the study area.

Source: NAMRIA (http://www.namria.gov.ph/) 


\section{Plot establishment}

The sampling protocol designed by Zemek (2009) was adopted with modification in this study. Three bamboo plantations were sampled, i.e. D. asper, B. blumeana, and B. vulgaris. Considering that the individual plantation area was comparably small and due to limited time and labor resources, only two sampling plots per bamboo plantation were purposively selected for a total of six plots. Each plot had a size of $5 \times 20 \mathrm{~m}\left(100 \mathrm{~m}^{2}\right)$ and contained two to three groups of clumping bamboo (Figure 2).

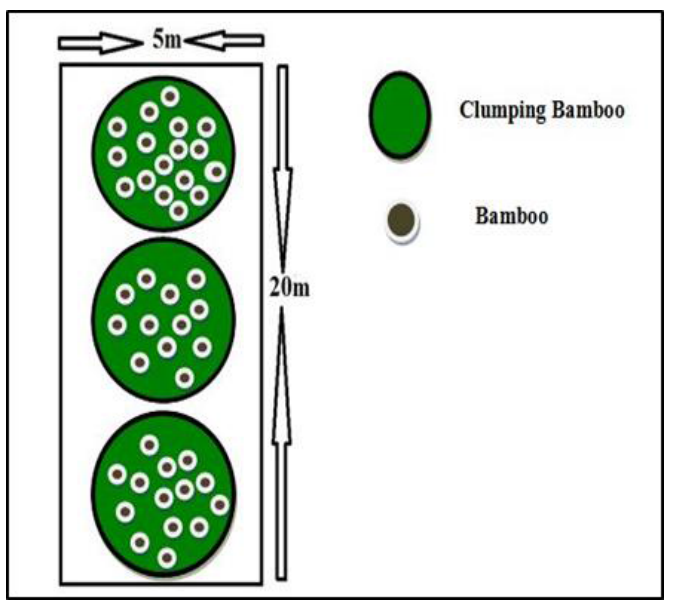

Figure 2. Diagram of a 5 x 20-m sampling plot.

\section{Measurement of aboveground biomass}

In each group of clumping bamboo within a $100-\mathrm{m}^{2}$ sampling plot, the following were determined: a) number of poles, b) total height of each pole using Haga altimeter, and c) diameter at breast height (1.3 $\mathrm{m}$ from the ground) of each pole using a diameter tape. Five individual poles in each clump were then randomly selected and sampled. After cutting each selected pole at breast height, total height was again determined with a measuring tape. Subsequently, aboveground components were separated into three: a) leaves, b) twigs and branches, and c) culms. Total fresh weight $(\mathrm{FW})$ of each component was determined on site with a scale and sub-sample of $300 \mathrm{~g}$ each was taken to the Soil and Plant Analysis 
Laboratory (SPAL) of Central Mindanao University in Musuan, Bukidnon for oven dry weight (DW) and carbon content determination. The equations below were used to convert sub-sample of dry biomass to total dry weight:

Total component DW $(\mathrm{kg})=$ total FW * sub-sample DW / sub-sample FW

Biomass total $(\mathrm{kg})=$ Average biomass per pole $*$ number of poles

\section{Calculation of aboveground carbon stock}

Carbon stock in each bamboo component was calculated based on its corresponding dry biomass and carbon content. The carbon stock in biomass was calculated using the following formula:

$$
C S i=T D W i * C F i
$$

where $C S i$ is carbon stock of component $i$ in $\mathrm{kg}, T D W i$ is total dry weight of component $i$ (biomass) in $\mathrm{kg}$, and $C F i$ is carbon content in biomass of component $i$ in percent. Total carbon stock was then calculated as the sum of carbon stock of all sampled components.

\section{Statistical analysis}

Analysis of variance (ANOVA) and post-hoc analysis (Tukey's HSD) were used to determine significant differences in terms of biomass and amount of carbon sequestered among the three species considered in the study.

\section{Results and Discussion}

\section{Biometric characteristic of bamboo species under study}

On the average, the number of poles per clump in the three bamboo species under study ranges from 25 to 29 with $D$. asper having the highest (Table 1). This range is consistent with the study of Rojo (2007) which showed that D. asper, B. blumeana and B. vulgaris had more or less 30 culms per clump. D. asper also had the greatest diameter and total height with a mean of $16.6 \mathrm{~cm}$ and $24.2 \mathrm{~m}$, respectively. Northern 
Mindanao Consortium for Agriculture and Resources Research and Development [NOMCARRD] (2009) reported that D. asper is a large bamboo species which can reach a diameter of $22 \mathrm{~cm}$ and total height of $30 \mathrm{~m}$. In contrast, B. blumeana had the smallest mean diameter at $7.3 \mathrm{~cm}$ only while $B$. vulgaris was the shortest with a mean height of $15.3 \mathrm{~m}$. It is noted though that $B$. blumeana can attain a diameter of up to $15 \mathrm{~cm}$ (Clayton et al., 2006) while $B$. vulgaris can grow an average height of up to $15 \mathrm{~m}$ (Rojo, 2007).

Table 1. Biometrics of the three bamboo species under study.

\begin{tabular}{|c|c|c|c|c|c|}
\hline \multirow{2}{*}{ Species } & \multirow{2}{*}{$\begin{array}{c}\text { Number of Poles } \\
\text { Per Clump }\end{array}$} & \multicolumn{2}{|c|}{ DBH, cm } & \multicolumn{2}{|c|}{ Height, m } \\
\hline & & Range & Mean & Range & Mean \\
\hline \multicolumn{6}{|l|}{ D. asper } \\
\hline \multicolumn{6}{|l|}{ Plot 1} \\
\hline Clumping bamboo 1 & 29 & $16.0-16.9$ & 16.3 & $24.3-25.9$ & 24.9 \\
\hline Clumping bamboo 2 & 27 & $15.9-16.8$ & 17.1 & $23.5-27.8$ & 23.0 \\
\hline Clumping bamboo 3 & 30 & $15.9-16.8$ & 16.2 & $24.9-28.2$ & 24.4 \\
\hline \multicolumn{6}{|l|}{ Plot 2} \\
\hline Clumping bamboo 1 & 32 & $16.1-17.9$ & 17.3 & $20.9-25.8$ & 23.5 \\
\hline Clumping bamboo 2 & 29 & $15.8-17.1$ & 16.1 & $22.5-27.6$ & 25.4 \\
\hline Species Mean & 29 & & 16.6 & & 24.2 \\
\hline \multicolumn{6}{|l|}{ B. blumeana } \\
\hline \multicolumn{6}{|l|}{ Plot 1} \\
\hline Clumping bamboo 1 & 23 & $4.0-8.5$ & 6.8 & $15.0-24.3$ & 19.2 \\
\hline Clumping bamboo 2 & 25 & $4.1-9.3$ & 7.5 & $16.2-25.0$ & 18.9 \\
\hline \multicolumn{6}{|l|}{ Plot 2} \\
\hline Clumping bamboo 1 & 26 & $5.1-8.6$ & 7.9 & $15.9-24.2$ & 20.3 \\
\hline Clumping bamboo 2 & 25 & $4.5-10.0$ & 8.1 & $15.9-24.9$ & 19.9 \\
\hline Clumping bamboo 3 & 24 & $4.2-11.4$ & 6.3 & $15.2-25.0$ & 20.5 \\
\hline Species Mean & 25 & & 7.3 & & 19.8 \\
\hline \multicolumn{6}{|l|}{ B. vulgaris } \\
\hline \multicolumn{6}{|l|}{ Plot 1} \\
\hline Clumping bamboo 1 & 28 & $5.0-8.9$ & 8.4 & $10.2-19.8$ & 15.4 \\
\hline Clumping bamboo 2 & 25 & $6.1-9.0$ & 7.8 & $10.5-20.0$ & 14.8 \\
\hline \multicolumn{6}{|l|}{ Plot 2} \\
\hline Clumping bamboo 1 & 27 & $5.5-10.0$ & 8.4 & $11.5-19.5$ & 15.2 \\
\hline Clumping bamboo 2 & 25 & $5.8-9.8$ & 7.4 & $10.0-20.1$ & 15.9 \\
\hline Species Mean & 26 & & 8.0 & & 15.3 \\
\hline
\end{tabular}




\section{Aboveground biomass density of bamboo species under study}

As one of the fastest-growing plants, bamboos typically mature in less than 10 years bearing an increment biomass of 5 to $12 \mathrm{t} \mathrm{ha}^{-1} \mathrm{yr}^{-1}$ (Lobovikov et al., 2009). Consequently, this plant could produce a high amount of biomass at a faster rate. As presented in Table 2, culms constitute the bulk of the aboveground biomass of the three bamboo species which ranges from $38.8 \%$ to $62.5 \%$ of the total. Düking et al. (2011) reported that culms possess the greatest capacity in terms of storing carbon in the live biomass of bamboos. D. asper yielded the highest aboveground biomass density with a mean of $177.63 \mathrm{t} \mathrm{ha}^{-1}$ which is statistically different when compared with the other two species. This value is comparable to that of other bamboo species such as a 12-year old Gigantochloa levis grown in the Philippines and a mature plantation of Phyllostachys pubescens in Japan which has an aboveground biomass of $146.8 \mathrm{t} \mathrm{ha}^{-1}$ and $137.9 \mathrm{t} \mathrm{ha}^{-1}$, respectively (Suzuki \& Jacalne, 1986; Isagi et al., 1997). This biomass value is even higher than that of the fastgrowing Gmelina arborea $\left(127 \mathrm{t} \mathrm{ha}^{-1}\right)$, which is used in forest plantations in the Philippines. The high biomass value of $D$. asper could be attributed to its relatively greater diameter and height, and the superior number of poles per hectare.

In contrast, $B$. blumeana and B. vulgaris produced significantly lower aboveground biomass density with a mean of $97.5 \mathrm{t} \mathrm{ha}^{-1}$ and $72.2 \mathrm{t} \mathrm{ha}^{-1}$, respectively. The lower biomass values of these two species could be due to their lesser diameter and height values. For instance, mean diameter and height values of $B$. blumeana are only $7.3 \mathrm{~cm}$ and $19.8 \mathrm{~m}$ while that of $B$. vulgaris are only $8.0 \mathrm{~cm}$ and $15.3 \mathrm{~m}$, respectively. As observed during the conduct of the study, D. asper was apparently well-managed while the two other bamboo species seemingly lacked proper care and maintenance as proliferating weeds such as grasses, and other vegetation are evident in the plantations (Figure 3). Virtucio and Roxas (2003) indicated that poor management practices in bamboo plantations may contribute to reduced production of culms and shoots. The biomass values of these species are expected though to increase as soon as they mature even in poorly managed stands. For instance, reported biomass of a mature plantation of B. blumeana in the Philippines is $143 \mathrm{t} \mathrm{ha}^{-1}$ (Isagi et al., 1997). 
Table 2. Aboveground biomass density of each bamboo species under study.

\begin{tabular}{|c|c|c|c|c|}
\hline Species & $\begin{array}{l}\text { Aboveground Plant } \\
\text { Component }\end{array}$ & $\begin{array}{c}\text { Component } \\
\text { Biomass in each } \\
\text { pole, } \mathrm{kg}\end{array}$ & $\begin{array}{l}\text { No. of } \\
\text { Poles Per } \\
\text { Hectare }\end{array}$ & $\begin{array}{c}\text { Aboveground } \\
\text { Biomass Density, } \\
\text { t ha }^{-1}\end{array}$ \\
\hline \multicolumn{5}{|l|}{ D. asper } \\
\hline \multirow{3}{*}{ Plot 1} & Leaves & 3.4 & 8600 & 29.2 \\
\hline & Twigs and branches & 6.3 & 8600 & 54.4 \\
\hline & Culm & 16.2 & 8600 & 139.7 \\
\hline \multirow[t]{2}{*}{ Total } & & 25.9 & & 223.3 \\
\hline & Leaves & 3.2 & 6100 & 19.5 \\
\hline \multirow[t]{2}{*}{ Plot 2} & Twigs and branches & 6.6 & 6100 & 40.1 \\
\hline & Culm & 11.9 & 6100 & 72.4 \\
\hline Total & & 21.7 & & 132.0 \\
\hline Species Mean & & 23.8 & & 177.6 \\
\hline \multicolumn{5}{|l|}{ B. blumeana } \\
\hline \multirow{3}{*}{ Plot 1} & Leaves & 2.6 & 4800 & 12.5 \\
\hline & Twigs and branches & 5.0 & 4800 & 24.2 \\
\hline & Culm & 9.5 & 4800 & 45.6 \\
\hline \multirow[t]{2}{*}{ Total } & & 17.1 & & 82.3 \\
\hline & Leaves & 2.3 & 7500 & 17.6 \\
\hline \multirow[t]{2}{*}{ Plot 2} & Twigs and branches & 5.2 & 7500 & 39.0 \\
\hline & Culm & 7.5 & 7500 & 56.2 \\
\hline Total & & 15.0 & & 112.8 \\
\hline Species Mean & & 16.1 & & 97.5 \\
\hline \multicolumn{5}{|l|}{ B. vulgaris } \\
\hline \multirow{3}{*}{ Plot1 } & Leaves & 4.3 & 5300 & 22.7 \\
\hline & Twigs and branches & 3.9 & 5300 & 20.6 \\
\hline & Culm & 5.4 & 5300 & 28.6 \\
\hline \multirow[t]{2}{*}{ Total } & & 13.6 & & 71.9 \\
\hline & Leaves & 4.4 & 5200 & 22.9 \\
\hline \multirow[t]{2}{*}{ Plot 2} & Twigs and branches & 4.1 & 5200 & 21.5 \\
\hline & Culm & 5.4 & 5200 & 28.1 \\
\hline Total & & 13.9 & & 72.5 \\
\hline Species Mean & & 13.8 & & 72.2 \\
\hline
\end{tabular}



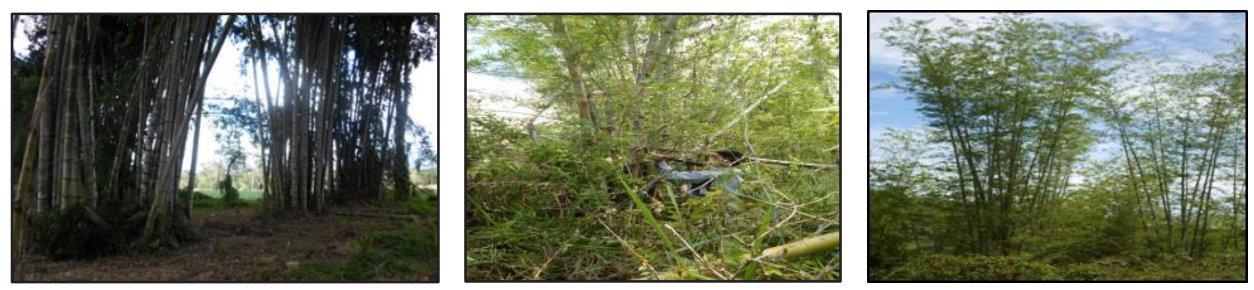

Figure 3. From left to right are plantations of $D$. asper, B. blumeana, and $B$. vulgaris in Bukidnon. Note the apparent difference of the three plantations in terms of care and maintenance particularly weeding practices.

\section{Aboveground carbon density of bamboo species under study}

Considered as the tallest grass, bamboo is known to be one of the fastest-growing plants in the world which can develop at the rate of up to $1.2 \mathrm{~m} \mathrm{day}^{-1}$ (Lobovikov et al., 2009). Since it can grow vigorously, it has great potential to sequester atmospheric carbon at a faster rate and be a valuable sink for carbon storage. Aboveground carbon storage is obtained by getting the product of organic carbon content in the biomass and the aboveground biomass density. Mean organic carbon content of the three species in this study ranges from 46.01 to $49.18 \%$ as shown in Tables 3 and 4. INBAR (2009) reported that about half (50\%) of the total biomass of bamboos is carbon. Meanwhile, average aboveground carbon density of $D$. asper is $86.7 \mathrm{tC} \mathrm{ha}^{-1}$ which is statistically higher compared to those of $B$. blumeana and $B$. vulgaris. This is comparable to a fast-growing Philippine forest plantation species, Acacia sp., which yields a carbon density of $81 \mathrm{tC} \mathrm{ha}^{-1}$ (Lasco et al., 2000). It is, however, about $17 \%$ only of the carbon density of natural forest which is $518 \mathrm{tC} \mathrm{ha}^{-1}$.

On the other hand, carbon density values of B. blumeana and B. vulgaris which are not statistically different from each other are roughly similar to that of another forest plantation species, Tectona grandis, which only has $35 \mathrm{tC} \mathrm{ha}^{-1}$. The aboveground carbon density value of B. vulgaris (33.4 $\mathrm{tC} \mathrm{ha}^{-1}$ ) is also comparable to that of a coconut-based multi-storey system in Mt. Makiling, Philippines which yields $39 \mathrm{tC} \mathrm{ha}^{-1}$ (Zamora, 1999). Planting bamboos however is better off than allowing the land to become idle and vegetated with grasses. While grasslands also have the 
ability to sequester carbon, it is reported that Imperata- and Saccharumdominated grasslands have only an aboveground carbon density values of 1.7 and $13.1 \mathrm{tC} \mathrm{ha}^{-1}$, respectively (Lasco, 2007).

Table 3. Total carbon stored in the aboveground biomass of three bamboo species under study.

\begin{tabular}{|c|c|c|c|c|}
\hline Species & $\begin{array}{l}\text { Mean Organic } \\
\text { Carbon } \\
\text { Content, } \%\end{array}$ & $\begin{array}{l}\text { Aboveground } \\
\text { Biomass } \\
\text { Density, } \mathrm{t} \mathrm{ha}\end{array}$ & $\begin{array}{l}\text { Aboveground } \\
\text { Carbon } \\
\text { Density, tC } \text { ha }^{-1}\end{array}$ & $\begin{array}{c}\text { Carbon Mean } \\
\text { Annual } \\
\text { Increment, } \\
\text { t ha }^{-1} \mathbf{y r}^{-1}\end{array}$ \\
\hline \multicolumn{5}{|c|}{$\begin{array}{c}\text { D. asper } \\
(27 \text { years old })\end{array}$} \\
\hline Plot 1 & 48.41 & 223.3 & 108.1 & 4.0 \\
\hline Plot 2 & 49.18 & 132.0 & 64.9 & 2.4 \\
\hline Mean & 48.8 & 177.6 & 86.7 & 3.2 \\
\hline \multicolumn{5}{|c|}{$\begin{array}{l}\text { B. blumeana } \\
\text { ( } 24 \text { years old) }\end{array}$} \\
\hline Plot 1 & 46.76 & 82.3 & 38.5 & 1.6 \\
\hline Plot 2 & 47.62 & 112.8 & 53.7 & 2.2 \\
\hline Mean & 47.19 & 97.5 & 46.1 & 1.9 \\
\hline \multicolumn{5}{|c|}{$\begin{array}{l}\text { B. vulgaris } \\
\text { (24 years old) }\end{array}$} \\
\hline Plot 1 & 46.01 & 71.9 & 33.1 & 1.4 \\
\hline Plot 2 & 46.41 & 72.5 & 33.6 & 1.4 \\
\hline Mean & 46.21 & 72.2 & 33.4 & 1.4 \\
\hline
\end{tabular}

Table 4. One-way ANOVA of aboveground biomass and carbon stored in the three bamboo species.

\begin{tabular}{|c|c|c|c|}
\hline Species & $\begin{array}{l}\text { Mean Aboveground } \\
\text { Biomass Density, } \mathrm{t} \mathrm{ha}^{-1}\end{array}$ & $\begin{array}{c}\text { Mean Aboveground } \\
\text { Carbon Density, } \mathrm{tC} \mathrm{ha}^{-1}\end{array}$ & $\begin{array}{c}\text { Statistical } \\
\text { Test }(\alpha=0.01)\end{array}$ \\
\hline D. asper & $177.6^{\mathrm{a}}$ & $86.7^{\mathrm{a}}$ & \\
\hline B. blumeana & $97.5^{\mathrm{b}}$ & $46.1^{\mathrm{b}}$ & 0.000 \\
\hline B. vulgaris & $72.2^{\mathrm{b}}$ & $33.4^{\mathrm{b}}$ & \\
\hline
\end{tabular}

Note: Means with the same letter superscript within a column are not statistically different from each other.

In terms of rate of carbon sequestration, each year the 27 year-old $D$. asper can sequester an average of $3.2 \mathrm{tC} \mathrm{ha}^{-1}$ while the 24 year-old B. blumeana and B. vulgaris can absorb only about 1.9 and $1.4 \mathrm{tC} \mathrm{ha}^{-1}$, respectively. These values are lower than that of a native bamboo in China called Moso bamboo (Phyllostachys heterocycla) which has an annual increment of $5.1 \mathrm{tC} \mathrm{ha}^{-1}(\mathrm{Li}, 2013)$. The carbon sequestration rate of 
D. asper is also a little bit lower than that of the 60 year-old Pinus kesiya plantation grown in Malaybalay City which has a rate of $3.99 \mathrm{tC} \mathrm{ha}^{-1} \mathrm{yr}^{-1}$ (Patricio \& Tulod, 2010). The low carbon sequestration rates of bamboo species in this study can be attributed to the constant harvesting of the stands leading to the reduction in their biomass. However, bamboos actually sequester more carbon during early years of plantation than fastgrowing forest trees because of their fast growth rate (Kuehl \& Castillo, 2012). In fact, Sakurai et al. (1994) reported that reforestation species in Nueva Ecija, Philippines such as Acacia auriculiformis, Tectona grandis, Gmelina arborea and $P$. kesiya with ages ranging from 6-13 years old had carbon sequestration rates between 0.55 to $3.73 \mathrm{tC} \mathrm{ha}^{-1} \mathrm{yr}^{-1}$ only.

\section{Conclusion and Recommendations}

The results of the study indicate that the three bamboo species grown in plantations in Bukidnon, Philippines have the potential to store atmospheric carbon. Aboveground carbon density of these species goes in the following order: D. asper (86.7 tons $\left.\mathrm{C} \mathrm{ha}^{-1}\right)>B$. blumeana (46.1 tons $\left.\mathrm{C} \mathrm{ha}{ }^{-1}\right)>$ B. vulgaris (33.4 tons $\mathrm{C} \mathrm{ha}^{-1}$ ). These represent $6.4-16.7 \%$ of the carbon stored in natural forests in the Philippines.

It is highly recommended that plantation managers and caretakers should incorporate appropriate silvicultural management practices that would enhance higher biomass production and greater carbon sequestration potential of these bamboo-stands. Policies and programs that advocate the establishment of bamboo plantations particularly using $D$. asper species in degraded, marginal and idle lands in the country should also be supported. While bamboos provide local communities with wide socioeconomic benefits, their ecological importance particularly in climate change mitigation should be recognized, highlighted and advocated in the policymaking, and research and development arena.

\section{Acknowledgment}

The authors would like to express their heartfelt appreciation to Dr. Michael Arieh P. Medina and For. Adrian M. Tulod for sharing their ideas and time in the conduct and manuscript writing of this study. CEDAR and the LGUs of Impasugong and Malaybalay City are likewise gratefully acknowledged. 


\section{Literature Cited}

Clayton, W. D., Vorontsova, M. S., Harman, K. T., \& Williamson, H. (2006). GrassBase - The Online World Grass Flora. Retrieved from http://www.kew.org/data/grasses-db.html

Decipulo, M. S., Ockerby, S., \& Midmore, D. J. (2009). Managing clumps of Dendrocalamus asper in Bukidnon, the Philippines. In D. J. Midmore (Ed.), Silvicultural management of bamboo in the Philippines and Australia for shoots and timber. Proceedings of a workshop held in Los Baños, the Philippines on 22-23 November 2006. Retrieved from http://aciar.gov.au/files/node /10532/PR129\%20 Part\%202.pdf on July 11, 2014.

Düking, R., Gielis, J., \& Liese, W. (2011). Carbon flux and carbon stock in a bamboo stand and their relevance for mitigating climate change. In: Bamboo Science and Culture. The Journal of the American Bamboo Society, 24(1), 1-6. Retrieved from http://www.bamboo.org /publications/e107_files/downloads/ BSCv $24 \% 20$ Lo-Res\%205-26.pdf on July 8, $201 \overline{4}$

International Network for Bamboo and Rattan. (2009). Bamboo: Roles in climate change, carbon sequestration and poverty alleviation under the Clean Development Mechanism of the Kyoto Protocol.

IPCC. (2013). Climate change 2013: The physical science basis summary for policymakers. Working Group I Contribution to the IPCC Fifth Assessment Report. 27 September 2013.

Isagi Y., Kawahara T., Kamo K., \& Ito, H. (1997). Net production and carbon cycling in a bamboo Phyllostachys pubescens stand. Plant Ecology, 130, 41-52. 
Kuehl, Y., \& Castillo, J. A. A. (2012). The potential role of bamboo in combating climate change and in REDD +. Canopy International, $38(1-6)$.

Lasco, R. D. (2007). Carbon stocks and sequestration of Philippine land use systems. In R. D. Lasco \& A. Flor (Eds.), Agroforestry and land use in the Philippines (pp. 149-201). Bogor, Indonesia: World Agroforestry Centre.

Lasco, R. D., Pulhin F. B., Visco, R. G., Racelis, D. A., Guillermo, I. Q., \& Sales, R. F. (2000, February). Carbon stocks assessment of Philippine forest ecosystems. Paper presented at the Science-Policy Workshop on Terrestrial Carbon Assessment for Possible Carbon Trading, Bogor, Indonesia.

Lobovikov, M., Lou, Y., Schoene, D., \& Widenoja, R. (2009). The poor man's carbon sink: Bamboo in climate change and poverty alleviation. FAO Working Document No. 8. FAO, Rome. Retrieved from ftp:// ftp.fao.org/docrep/fao /012/k6887e / k6887e00.pdf

Maoyi, F. (2007). Sustainable management and utilization of sympodial bamboos. Retrieved from www.bamboocarboncredits.com

Municipal Planning and Development Office. (2003). Impasugong socioeconomic profile 2000. Impasugong, Bukidnon.

Municipal Planning and Development Office. (2000). 2001-2010 Comprehensive land use plan of the Municipality of Impasugong. Impasugong, Bukidnon.

Northern Mindanao Consortium for Agriculture and Resources Research and Development. (2009). Propagation of giant bamboo by branch cutting. Information Bulletin No. 261/2009. 
Patricio, J. H. P., \& Tulod, A. M. (2010). Carbon sequestration potential of Benguet Pine (Pinus kesiya) plantations in Bukidnon, Philippines. Journal of Nature Studies, 9(1), 99-104.

Rojo, J. (2007). Bamboo resources of the Philippines. In E. Navera, S. M. Pablico and S. C. Malab (Eds.), Ang kawayan. Paper presented at the Proceedings of the First National Conference on Bamboo, Iloilo City, 1-3 August 1996. Retrieved from http://aciar.gov.au/files/node/10532/PR129\%20Part \%203.pdf

Sakurai, S., Ragil, R. S. B., \& de la Cruz, L. U. (1994). Tree growth and productivity in degraded forest land. In Rehabilitation of Degraded Lands in the Tropics. Paper presented at JIRCAS International Symposium Series No. 1, Japan International Research Center for Agricultural Sciences (JIRCAS), Tsukuba, Japan (pp. 64- 71).

Suzuki, T., \& Jacalne, D. (1986). Above-ground biomass and the growth of bamboo stands in the Philippines. Japan Agricultural Research Quarterly, 20(1), 85-91.

Virtucio, F. D., \& Roxas, C. A. (2003). Bamboo production in the Philippines. Ecosystems Research and Development Bureau, Department of Environment and Natural Resources, College, Laguna, Philippines.

Zamora, D. (1999). Carbon dioxide $\left(\mathrm{CO}_{2}\right)$ storage potential of multistorey agroforestry systems in Mt. Makiling. [Unpublished MS Thesis]. University of the Philippines, College, Laguna, Philippines.

Zemek, O. J. (2009). Biomass and carbon stocks inventory of perennial vegetation in the Chiengkhoi Watershed, NW Vietnam. [Unpublished MS Thesis]. Department for Agroecology and Plant Production in the Tropics and Subtropics. Retrieved from https://www.uni-hohenheim. De /sfb564/ public/ c4_files /zemek_msc.pdf on September 10, 2012 